\title{
STUDY REGARDING VARIABILITY OF YIELD COMPONENTS IN SOME GRAPEVINE VARIETIES FOR WHITE WINES
}

\author{
Giancarla Velicevici ${ }^{1}$, Emilian Madoşă $^{1} *$, Adriana Ciulca ${ }^{1}$, Sorin Ciulca ${ }^{1}$, Camen Dorin $^{1}$, \\ Mihaela Mălăescu ${ }^{1}$, Renato Coradini ${ }^{2}$ \\ ${ }^{1}$ Banat's University of Agricultural Sciences and Veterinary Medicine „King Michael I from Romania” Timişoara, \\ Calea Aradului 119, Timişoara, Romania \\ ${ }^{2}$ S.C.Vigna d'oro Arad, Romania
}

\begin{abstract}
The purpose of the study was to evaluate the variability of several white wine grape varieties in order to highlight their main quantitative and qualitative parameters. The study was carried out during two growing seasons (2017-2018) in the Pâncota locality area, Arad County, in the pedo-climatic conditions from the Miniş-Măderat vineyard. Research was organized in randomized block design with three replications. The morphological parameters involved in the research were: the number of bunches on the vine, the bunch weight, the number of berries in the bunch and the grape yield on the vine. The highest number of bunches on the vine was recorded in the Pinot Gris and Italian Riesling varieties, while the Traminer Rose variety recorded the lowest values for the same parameter. The Muscat Ottonel variety recorded the highest values for the average weight of the bunch, with very significant positive results. The Muscat Ottonel variety also recorded the highest number of berries / bunch during the research. The same variety achieved the highest yield, of $3027.10 \mathrm{~g} /$ vine, significantly higher than the other varieties, with over 141.5\% compared to Pinot Gris, to over $180 \%$ compared to Traminer Rose. In the Traminer Rose variety, lower values of the grape yield on the vine were recorded, suggesting a specific adaptation of the variety to less favourable environmental conditions. Therefore, this variety can return lower but constant yields in the unfavourable environmental conditions.
\end{abstract}

Keywords: grapevine, quantitative parameters, variability, yield

\section{INTRODUCTION}

It is believed that the grape is one of the first fruit cultivated by mankind. Grapes are the berry fruit of the deciduous woody vines belonging to Vitaceae family and Vitis genus. The grape achieved its popularity for the high nutritious value, excellent in taste, multipurpose use and high yields (Ghosh SN. et al., 2008). Grapevine (Vitis spp.) is all over the world one of the most important fruit species, with multiple uses of grape berries in the wine production, grape juice and other grapevine byproducts. Grapes have a connection with an ancient historical development of human culture. In the earliest writings and archives associated to all kind of agricultural and religious activities, grapevine and its by-products were given a significant place (Thomas et al., 1993; Vivier, 2000).

Grape cultivation is highly dependent upon climate. Winegrowing requires very special conditions, namely: an average growing-season temperature between $12^{\circ} \mathrm{C}$ to $24^{\circ} \mathrm{C}$ (Jones, 2007; Ramos et al., 2013) and appropriate mesoclimatic conditions, solar radiation, precipitation and evaporation 
(Hopphman, 1988; Van Leeuwen et al., 2004). Nemani et al. (2001) have stated that grape quality is affected by solar radiation and rainfall, frost intensity and duration, temperature variability and humidity levels during the growing season. According to Hunter and Bonnardot (2011), temperatures from $25^{\circ} \mathrm{C}$ to $30^{\circ} \mathrm{C}$, wind speed of less than $4 \mathrm{~m} / \mathrm{s}$ and relative humidity between $60 \%$ and $70 \%$ are required for optimum vine photosynthetic activity. Variations in microclimatic and mesoclimatic conditions may influence the perspective for viticulture at higher altitudes and in coastal areas (Fraga et al., 2012). Hence climate plays an important role in the development of grapes such as berry growth and development, berry maturity, ripening, development of physical, as well as chemical characteristics of the berry quality such as size, colour, aroma, and accumulation of anthocyanin's (Jackson et. al., 1993). The maturity, ripening, and harvesting time of grapes depend upon cultivar, geographic location, and agro climatic conditions. Different table grapes cultivars have been found to have varying tolerance to temperature, heat stress, rainfall and their distribution along the growing season (Cameron et. al., 2004). Climate influence the vine in all stages of development, but extreme temperatures are those that can cause irreversible damage (Dobrei et. al., 2014). High temperatures during ripening are beneficial for the accumulation of sugars, anthocyanin's, flavours, acidity, while low temperatures in early bud-break stage can cause great damage to grapevine or in harvest season when yield and quality of grapes and wine are influenced (Jordão, 2015). The purpose of the study was to evaluate the variability of some grapevine varieties for white wine in order to highlight the quantitative differences between these varieties.

\section{MATERIALS AND METHODS}

Four grape varieties for white wines were involved in the research: Pinot Gris, Traminer Rosé, Muscat Ottonel and Italian Riesling. The study was carried out during two years (2017-2018) on the Pâncota locality area, Arad County, in the pedo-climatic conditions from the Miniş-Măderat vineyard. During the research, were recorded the precipitation and air temperature, by using data from the Meteobot@Pro weather station installed in the vineyard. There were also dry periods such as July 2017, or September 2018.

In both growing seasons, the lowest temperatures were recorded in January and the highest in August. The temperatures from autumn and the beginning of winter were similar during research years. The beginning of winter was cold in 2017, but the months of December, February and March were the warmest compared to similar months from 2018. The experiment was organised in randomized block design with three replications. The researches and observations were carried out following the application of the technology specific to the conventional grapevine growing, with observations for all the technological links concerning the grapevine regular pruning and the soil management.

The cane training system was $90 \mathrm{~cm}$ Guyot (Traminer Rosé variety), respectively simple Cordon (white varieties: Pinot Gris, Riesling Italian, Muscat Ottonel) with planting distances between rows of $2.4 \mathrm{~m}$ and $0.9 \mathrm{~m}$ spacing between vines on row, resulting the density of 4630 vines per hectare. The pruning system was mixed, with the fruit load of 6-8 eyes / cane for the Traminer Rosé variety, and 12 eyes / cane for the white varieties: Pinot Gris, Italian Riesling, and Muscat Ottonel. This crop load is practiced in order to obtain quality and not quantity. The morphological parameters involved in the research were: the number of bunches / vine, the bunch weight, the number of berries / bunch and the yield of bunches on vine. Data were statistically analysed using the two-way 


\section{Current Trends in Natural Sciences}

Vol. 9, Issue 17, pp. 97-103, 2020

https://doi.org/10.47068/ctns.2020.v9i17.011

Current Trends in Natural Sciences (on-line)

ISSN: 2284-953X

Current Trends in Natural Sciences (CD-Rom)

ISSN: 2284-9521

ISSN-L: 2284-9521

ISSN-L: 2284-9521

analysis of variance (ANOVA). The significance of differences between the varieties was noted with symbols $(*, 0)$ (Ciulca, 2006).

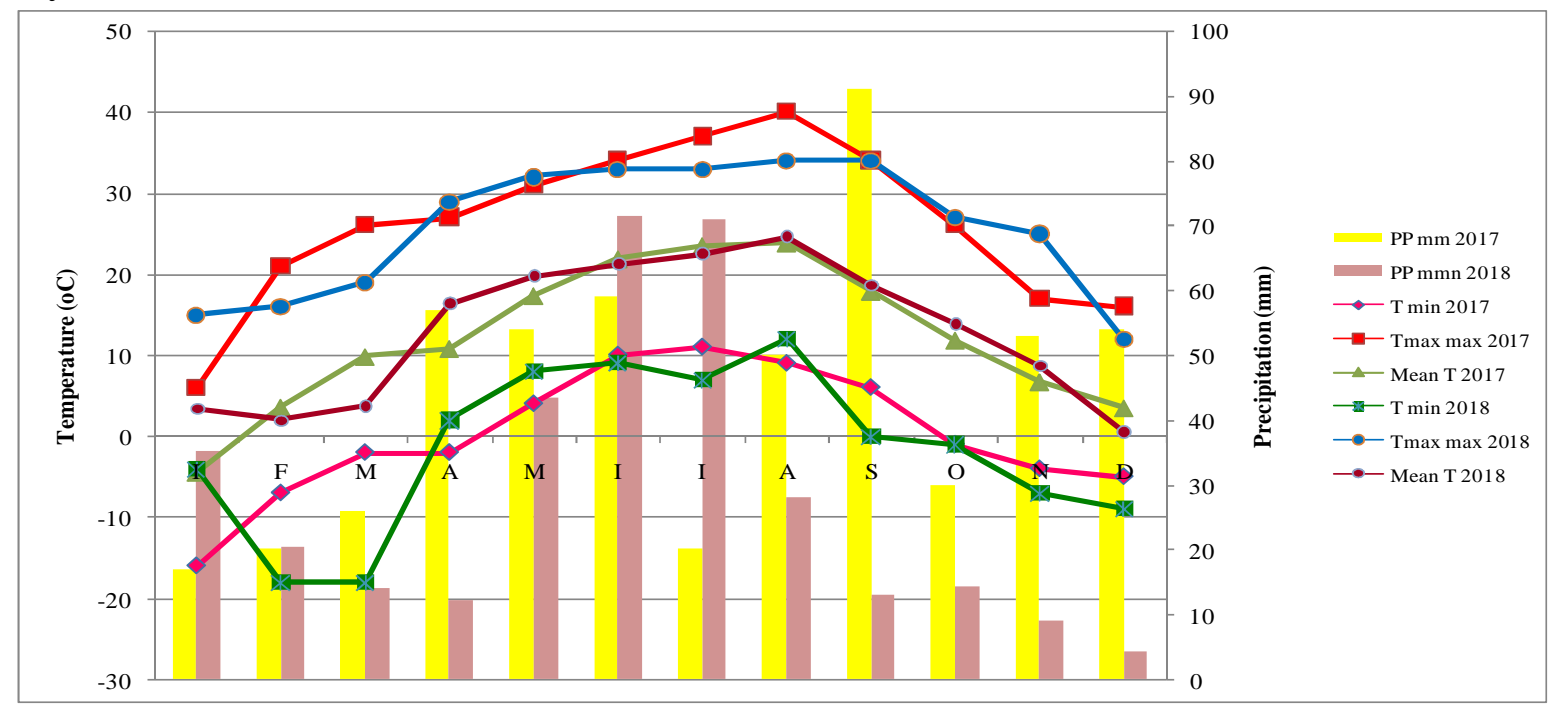

Figure 1. Temperature and precipitations during growing seasons (2017-2018)

\section{RESULTS AND DISCUSSIONS}

Following the study was found some differences in the parameters among the different grape's varieties, such as: the bunches number / vine along with the weight of bunches are components that reflect the fertility and productivity of the grapevine varieties (Leonte, 1996; Sestras, 2004) and moreover, express the correct value of grape production (Oprea, 2007).

According to presented data (Table 1) it could be observed that, climate conditions during research influenced the number of bunches/vine in all studied genotypes. The number of bunches/vine, ranged between 25.45 bunches /vine in 2017 and 26.76 bunches /vine in 2018. The higher level of rainfall in 2018 had a positive influence on the inflorescences primordial initiation and bunch development.

Table 1. The effect of the climatic conditions during research on the bunch number /vine

\begin{tabular}{|c|c|c|c|c|c|}
\hline Growing season & \multicolumn{2}{|c|}{$\begin{array}{c}\text { Relative } \\
\text { Average (g) }\end{array}$} & $\begin{array}{c}\text { Statistical } \\
\text { vignificance }\end{array}$ \\
\hline 2017- 2018 & 26.7625 & 25.4567 & 105.13 & 1.3058 & - \\
\hline & & & LDS 5\% & LDS 1\% & LDS 0.1\% \\
\hline & & & 5.270 & 7.981 & 12.821 \\
\hline
\end{tabular}

The highest bunch number /vine was recorded in Italian Riesling (29.251) and Pinot Gris (28.083) varieties, while the Traminer variety recorded the lowest values for this parameter (20.78) (Table 2). However, Italian Riesling registered significant difference compared with Traminer Rose variety.

The average bunch weight is an important parameter because it is involved in both grapevine productivity and in the wine quality (Sestraş, 2004). Moreover, as most researchers found, the average bunch weight is one of the deciding factors for grape yield/vine and harvested production (Oprea, 2001; Dumitru, 2008). 


\section{Current Trends in Natural Sciences}

Vol. 9, Issue 17, pp. 97-103, 2020

https://doi.org/10.47068/ctns.2020.v9i17.011

Current Trends in Natural Sciences (on-line)

Table 2. The effect of grapevine varieties on the bunch number /vine

\begin{tabular}{|l|c|c|c|c|c|}
\hline \multicolumn{1}{|c|}{ Varieties } & \multicolumn{2}{c|}{$\begin{array}{c}\text { Average (number of } \\
\text { bunch/vine) }\end{array}$} & $\begin{array}{c}\text { Relative } \\
\text { value\% }\end{array}$ & Difference & $\begin{array}{c}\text { Statistical } \\
\text { significance }\end{array}$ \\
\hline Traminer Rose- Pinot Gris & 20.7850 & 28.0833 & 74.01 & -7.2983 & - \\
\hline Riesling Italian - Pinot Gris & 29.2517 & 28.0833 & 104.16 & 1.1683 & - \\
\hline Muscat Ottonel - Pinot Gris & 26.3183 & 28.0833 & 93.72 & -1.7650 & - \\
\hline Riesling Italian - Traminer Rose & 29.2517 & 20.7850 & 140.73 & 8.4667 & $*$ \\
\hline Muscat Ottonel - Traminer Rose & 26.3183 & 20.7850 & 126.62 & 5.5333 & - \\
\hline Muscat Ottonel - Riesling Italian & 26.3183 & 29.2517 & 89.97 & -2.9333 & - \\
\hline & & & LDS 5\% & LDS 1\% & LDS 0.1\% \\
\hline & & & 7.468 & 10.286 & 14.161 \\
\hline
\end{tabular}

The results regarding the effect of climatic conditions during research on the bunch weight for the white grape varieties analysed are summarized in (Table 3). The bunch weight recorded values between 89.45 (g) in 2018 and $82.49 \mathrm{~g}$ in 2017 . Results confirm that the bunch weight was lower during 2017 growing season.

Table 3. The effect of climate during growing seasons on the bunch weight

\begin{tabular}{|c|c|c|c|c|c|}
\hline Growing season & \multicolumn{2}{|c|}{ Average (g) } & $\begin{array}{c}\text { Relative } \\
\text { value\% }\end{array}$ & Difference & $\begin{array}{c}\text { Statistical } \\
\text { significance }\end{array}$ \\
\hline 2017- 2018 & 89.4525 & 82.4942 & 108.43 & 6.9583 & $* * *$ \\
\hline & & & LDS 5\% & LDS 1\% & LDS 0.1\% \\
\hline & & & 2.658 & 4.025 & 6.466 \\
\hline
\end{tabular}

All varieties involved in the research showed different bunch weight; the highest bunch average weight was recorded in Muscat Ottonel (117.71 g) followed by Traminer Rose (81.48 g) while the lowest value was recorded in Italian Riesling (69.58 g) (Table 4).

Table 4. The effect of grapevine varieties on the bunch weight

\begin{tabular}{|c|c|c|c|c|c|}
\hline Varieties & \multicolumn{2}{|c|}{$\begin{array}{c}\text { Average of bunch } \\
\text { weight (g) }\end{array}$} & $\begin{array}{c}\text { Relative } \\
\text { value\% }\end{array}$ & Difference & $\begin{array}{c}\text { Statistical } \\
\text { significance }\end{array}$ \\
\hline Traminer Rose- Pinot Gris & 81.4850 & 75.1100 & 108.49 & 6.3750 & $* * *$ \\
\hline Riesling Italian - Pinot Gris & 69.5833 & 75.1100 & 92.64 & -5.5267 & oo \\
\hline Muscat Ottonel - Pinot Gris & 117.7150 & 75.1100 & 156.72 & 42.6050 & $* * *$ \\
\hline Riesling Italian - Traminer Rose & 69.5833 & 81.4850 & 85.39 & -11.9017 & OOO \\
\hline Muscat Ottonel - Traminer Rose & 117.7150 & 81.4850 & 144.46 & 36.2300 & $* * *$ \\
\hline Muscat Ottonel - Riesling Italian & 117.7150 & 69.5833 & 169.17 & 48.1317 & $* * *$ \\
\hline & & & LDS 5\% & LDS 1\% & LDS 0.1\% \\
\hline & & & 3.157 & 4.349 & 5.987 \\
\hline
\end{tabular}

The results of bunches weight $(\mathrm{g})$ showed a varying pattern among genotypes. Bunch weight differences in white grape varieties was attributed to inherent characters of each variety, to the difference in number of berries per bunch and to berry size (Walker et al., 2000; Havinal et al., 2008).

The climatic conditions in 2018 were less favourable for the berries number/bunch in white grape varieties (Table 5). 


\section{Current Trends in Natural Sciences}

Vol. 9, Issue 17, pp. 97-103, 2020

https://doi.org/10.47068/ctns.2020.v9i17.011

Current Trends in Natural Sciences (on-line)

ISSN: 2284-953X

ISSN-L: 2284-9521
Current Trends in Natural Sciences (CD-Rom)

ISSN: 2284-9521

ISSN-L: 2284-9521

Table 5.The effects of climate conditions during growing seasons on the number of berries /bunch

\begin{tabular}{|c|c|c|c|c|c|}
\hline Periods & \multicolumn{2}{|c|}{ Average (g) } & $\begin{array}{c}\text { Relative } \\
\text { value\% }\end{array}$ & Difference & $\begin{array}{c}\text { Statistical } \\
\text { significance }\end{array}$ \\
\hline $\mathbf{2 0 1 8 - 2 0 1 7}$ & 66.6854 & 77.2217 & 86.36 & -10.5363 & oo \\
\hline & & & LDS 5\% & LDS 1\% & LDS 0.1\% \\
\hline & & & 9.422 & 14.268 & 22.921 \\
\hline
\end{tabular}

Grape berry needs long warm, hot dry summer and cool rainy winter (Winkler et al., 1974). Climate play very important role during the berry maturation, ripening, or development of physical as well as chemical characteristics of the berry quality such as: size, colour, berry growth and development, aroma, accumulation of anthocyanin, etc. (Jackson, 1993).

All the varieties showed different number of berries per bunch. The number of berries/bunch was smaller, on average 64.18 berries/ bunch in the Pinot Gris variety and the maximum value of 83.26 berries/ bunch on average in the Muscat Ottonel variety. The number of berries per bunch is influenced by climate conditions during flowering and/or fruit set (Iland et al., 2013).

Table 6. The effect of grapevine varieties on the number of berries /bunches

\begin{tabular}{|c|c|c|c|c|c|}
\hline Variants & \multicolumn{2}{|c|}{$\begin{array}{c}\text { Average(number of } \\
\text { berries /bunches) }\end{array}$} & $\begin{array}{c}\text { Relative } \\
\text { value\% }\end{array}$ & Difference & $\begin{array}{c}\text { Statistical } \\
\text { significance }\end{array}$ \\
\hline Traminer - Pinot Gris & 70.0225 & 64.1808 & 109.10 & 5.8417 & - \\
\hline Riesling Italian - Pinot Gris & 70.3458 & 64.1808 & 109.61 & 6.1650 & - \\
\hline Muscat Ottonel - Pinot Gris & 83.2650 & 64.1808 & 129.73 & 19.0842 & - \\
\hline Riesling Italian - Traminer & 70.3458 & 70.0225 & 100.46 & 0.3233 & - \\
\hline Muscat Ottonel - Traminer & 83.2650 & 70.0225 & 118.91 & 13.2425 & - \\
\hline Muscat Ottonel - Riesling Italian & 83.2650 & 70.3458 & 118.37 & 12.9192 & - \\
\hline & & & LDS 5\% & LDS 1\% & LDS 0.1\% \\
\hline & & & 19.756 & 27.211 & 37.462 \\
\hline
\end{tabular}

Regarding the influence of the climatic conditions during research growing seasons, on the grape yield/vine, it is found that the growing season conditions from 2018 had a very significant positive influence on the grape yield / vine in all analysed varieties. The higher level of rainfall in 2018 had a positive influence on the bunch weight/ vine in the harvest time.

Table 7. The effect of growing season on the grape yield/ vine

\begin{tabular}{|c|c|c|c|c|c|}
\hline $\begin{array}{c}\text { Growing } \\
\text { season }\end{array}$ & \multicolumn{2}{|c|}{ Average (g) } & $\begin{array}{c}\text { Relative } \\
\text { value\% }\end{array}$ & Difference & $\begin{array}{c}\text { Statistical } \\
\text { significance }\end{array}$ \\
\hline $2018-2017$ & 2406.9442 & 2064.8350 & 116.57 & 342.1092 & $* * *$ \\
\hline & & & LDS 5\% & LDS 1\% & LDS 0.1\% \\
\hline & & & 13.867 & 20.998 & 33.732 \\
\hline
\end{tabular}

The average values of yield / vine for white wine varieties (Table 8) showed amplitude of 1353.67 $\mathrm{g}$, with limits from $1673.43 \mathrm{~g}$. in Pinot Gris to $3027.10 \mathrm{~g}$ in Muscat Ottonel.

The Muscat Ottonel variety achieved a significantly higher production than the other varieties during both growing seasons. A higher value of this parameter was also recorded in the Italian Riesling variety.

Table 8. The effect of grapevine varieties on the grape yield/vine 


\begin{tabular}{|l|c|c|c|c|c|}
\hline \multicolumn{1}{|c|}{ Variants } & \multicolumn{2}{c|}{ Average(g) } & $\begin{array}{c}\text { Relative } \\
\text { value\% }\end{array}$ & Difference & $\begin{array}{c}\text { Statistical } \\
\text { significance }\end{array}$ \\
\hline Traminer Rose - Pinot Gris & 1673.438 & 2139.348 & 78.22 & -465.9100 & 000 \\
\hline Riesling Italian - Pinot Gris & 2103.670 & 2139.348 & 98.33 & -35.6783 & 00 \\
\hline Muscat Ottonel - Pinot Gris & 3027.101 & 2139.348 & 141.50 & 887.7533 & $* * *$ \\
\hline Riesling Italian - Traminer Rose & 2103.670 & 1673.438 & 125.71 & 430.2317 & $* * *$ \\
\hline Muscat Ottonel - Traminer Rose & 3027.101 & 1673.438 & 180.89 & 1353.6633 & $* * *$ \\
\hline Muscat Ottonel - Riesling Italian & 3027.101 & 2103.670 & 143.90 & 923.4317 & $* * *$ \\
\hline & & & LDS 5\% & LDS 1\% & LDS 0.1\% \\
\hline & & & 20.806 & 28.657 & 39.453 \\
\hline
\end{tabular}

Muscat Ottonel achieved during research the highest yields of $3027.10 \mathrm{~g}$ respectively, and significantly higher than other varieties, with increases from $141.5 \%$ compared to Pinot Gris to $180 \%$ compared to Traminer Rose. In the Traminer Rose variety, lower values of yield/ vine were recorded, suggesting a special adaptation to less favourable environmental conditions. Therefore, this variety can return lower but constant grape yields in unfavourable environmental conditions.

\section{CONCLUSIONS}

For the analysed parameters, there are differences from one growing season to another. The highest number of bunches / vine was recorded in Italian Riesling (29.251) and Pinot Gris (28.083) varieties, while the Traminer variety recorded the lowest values (20.78). The Muscat Ottonel variety (117.71g) recorded the highest values of the average bunch weight with the results very significant positive.

Regarding the influence of the climatic conditions during research on the yield/ vine, it was found that the conditions of 2018 growing season had a very significant positive influence on the grape yield/ vine. The smallest productions were recorded for the Pinot Gris variety (1679 g / vine). Muscat Ottonel achieved in both growing seasons, the highest yields (3027.10 g) and significantly higher yields than the other varieties. The Muscat Ottonel variety was less influenced by the climatic conditions in both growing seasons (2017-2018).

\section{REFERENCES}

Cameron, I., Pasqual, G. (2004). Table Grapes from Western Australia at Glance. Horticulture Program, Agriculture Western Australia, Department of Agriculture WA. Bulletin, 4626.

Ciulca, S. (2006). Metodologii de experimentare in agricultura si biologie, [Experimental Methodologies in Agriculture and Biology], Agroprint Publishing House, Timişoara.

Dobrei, A., Dobrei. A.G., Sala, F., Nistor, E., Mălăescu, M., Dragunescu, A., Cristea, T. (2014). Research concerning the influence of soil maintenance on financial performance of vineyards, Journal of Horticulture, Forestry and Biotechnology 18(1), 156- 164.

Dumitriu, I.C. (2008). Viticultura [Viticulture]. Edit. Ceres, Bucureşti.

Fraga, H., Santos, J.A., Aureliano, C., Malheiro, J.P. (2012). An overview of climate change impacts on European viticulture. Food Energy Sec. 1(2), 94-110.

Ghosh, S.N., Tarai, R.K., Pal, P.P., (2008). Performance of eight grape cultivars in laterite soil of west Bengal. Proceedings of the International symposium on grape production and processing, Acta Horticulture, 73-77.

Havinal, M.N., Tambe, T.B., Patil, S.P. (2008). Performance of various grape vine varieties on yield and fruit quality attributes. Asian Journal of Horticulture, 3, 100-102.

Hopphman, D. (1988). Der Einflub von Jahreswitterung und Stadort auf die Mostgewicheteder Rebsorten Riesling und Muller-Thurgau (Vitis vinifera L.) [The influence of annual weather and location on the must quality of the Riesling and Muller-Thurgau grape varieties (Vitis vinifera L.)]. Thesis. Giessen. 


\section{Current Trends in Natural Sciences}

Vol. 9, Issue 17, pp. 97-103, 2020

https://doi.org/10.47068/ctns.2020.v9i17.011

Current Trends in Natural Sciences (on-line)

ISSN: 2284-953X

Current Trends in Natural Sciences (CD-Rom)

ISSN: 2284-9521

ISSN-L: 2284-9521

ISSN-L: 2284-9521

Hunter, J.J., Bonnardot, V. (2011). Suitability of some climatic parameters for grapevine cultivation in South Africa, with focus on key physiological processes. S. Afr. J. Enol. Vitic, 32(1), 137-154

Iland, P., Dry, P., Proffit, T., Tyerman, S. (2011). The grapevine: from the science to the practice of growing vines for wine. Patrick Iland Wine Promotions Pty Ltd. Adelaide, Australia.

Jackson, D.I., Lombard. P.B. (1993). Environment and management practices affecting grape composition and wine quality: a review. American Journal of Ecology and Viticulture 4, 409-430.

Jones, G.V., (2007). Climate Change: Observations, Projections, and General Implications for Viticulture and Wine Production. Practical Winery and Vineyard, July/August. 44-64

Jordão, A.M., Vilela, A., Cosme, F., (2015). Review: From sugar of grape to alcohol of wine: sensorial impact of alcohol in wine, Beverages, 1(4), 292-310; doi:10.3390/beverages 1040292

Leonte, C. (1996). Ameliorarea plantelor horticole - probleme generale [Improvement of horticultural plants - general issues]. Ed. Didactică şi Pedagogică Bucureşti.

Nemani, R.R., White, M.A., Cayan, D.R., Jones, G.V., Running, S.W., Coughlan, J.C., Peterson, D.L. (2001). Asymmetric warming over coastal California and its impact on the premium wine industry. Climate Res. 19(1), 25-34.

Oprea, Şt., Moldovan, S.D. (2007). Ameliorarea viței de vie în România [Grapevine improving in Romania] Editura Poliram Cluj-Napoca.

Oprea, Şt., (2001). Viticultură [Viticulture]. Edit. AcademicPres, Cluj Napoca.

Ramos, A.M., Lorenzo, N., Taboada, J., Lorenzo, J. (2013). Influence of climate variability on grape production and wine quality in the Rias Baixas, north-western Spain. EGU General Assembly Conference Abstracts 15, 3011.

Sestraş, R., (2004). Ameliorarea speciilor horticole. [Improvement of horticultural species].Ed. AcademicPres, ClujNapoca.

Thomas, M.R., Matsumoto, S., Cain, P., Scott, N.S., (1993). Repetitive DNA of grapevine: classes present and sequences suitable for cultivar identification. Theor Appl Genet, 86, 173-180.

Vivier, M.A., Pretorius, I.S. (2000). Genetic improvement of grapevine: tailoring grape varieties for the third millennium. South African Journal of Enology and Viticulture, 21, 5-26.

Walker, R.R., Read, P.E., Blackmore, D.H. (2000). Rootstock and salinity effects on rates of berry maturation, ion accumulation and colour development in Shiraz grapes. Australian Jr. Grape Wine Research, 6, 227-239

Winkler, A.J., Cook, J.A., Kliewer, W.M., Lider, L.A. (1974). General viticulture. University of California Press, Berkeley.

Van Leeuwen, C., Friant, P., Choné, X., Tregoat, O., Koundouras, S., Dubourdieu, D. (2004). Influence of climate, soil and cultivar on terroir. American Journal of Enology and Viticulture, 55, 207-217. 